\title{
Exemplary mentorship in action: Harvey Cushing's trainees from 1912 to 1919
}

\author{
Michael P. Catalino, MD, MSc, ${ }^{1,2}$ and Edward R. Laws Jr., MD1 \\ 'Department of Neurosurgery, Brigham and Women's Hospital, Boston, Massachusetts; and 'Department of Neurosurgery, \\ University of North Carolina Hospitals, Chapel Hill, North Carolina
}

\begin{abstract}
Harvey Cushing overcame tremendous obstacles to his personal and professional development from 1912 to 1919. These trials could have jeopardized the early and necessary formation of the Society of Neurological Surgeons in 1920. War separated young neurosurgeons pursuing the advancement of this "special field," but Cushing's principled mentoring of these aspiring surgeons in the midst of this demanding time was unwavering. This historical vignette is a collection of stories composed to highlight certain trainees during this period in his career. It also puts the mentoring relationship into a context that is often encountered today. There is much to learn from those who endure trials of any kind, but there is much more to learn from those, like Cushing, who inspire perseverance in others during their trials.
\end{abstract}

https://thejns.org/doi/abs/10.3171/2019.12.JNS192371

KEYWORDS Cushing; war; neurosurgery; mentorship; training; history

Difficulties squarely met and overcome by faithful work are the tests of character which show the reliable man from the fair-weather crowd of sailors.

$$
\text { - Henry R. Cushing to his son, Harvey; Yale } 1888
$$

Between 1912 and 1919, Harvey Cushing launched a career in a new surgical specialty; relocated his practice, family, and laboratory work; and served in World War I. At the turn of the century, Johns Hopkins was establishing the first residency program in general surgery under William Halsted. Until then, surgical training had followed the apprentice model. Cushing excelled and was offered orthopedic specialization, but he refused. Instead, he chose, despite limited experience, to focus on a new specialty: neurosurgery. His 1904 address to the Academy of Medicine of Cleveland introduced the "special field" of neurosurgery. ${ }^{7}$ Those interested in neurosurgical specialization found their pursuits challenged by war, which prevented advancements in organizational goals, but the seeds planted by Cushing in the midst of this unrest from 1912 to 1919 were cultivated into the formation of a society for the advancement of neurosurgical practice (Fig. 1). In 1920, Cushing, then 51 years old, mobilized the inaugural meeting of the Society of Neurological Surgeons. ${ }^{8}$

\section{Leaving Hopkins}

With great opportunity ahead of him, Cushing did not lose sight of his primary responsibility as teacher and role model at Hopkins. In fact, mentoring during the challenges of transition serves as an obvious example of integrity to one's trainees. A Sherlock Holmes joke describes Holmes awakening the sleeping Watson while camping to ask Watson to look up in the sky and tell him what he sees. Watson notes the astrological, horological, meteorological, and theological conclusions to be drawn from the millions of stars. Holmes replies, "Watson, you idiot! Someone has stolen our tent!" Thankfully, Harvey Cushing never lost sight of the importance of mentorship despite his opportunities in Boston. After accepting the offer at the Peter Bent Brigham Hospital at Harvard as the Moseley Professor of Surgery, he could have distanced himself from trainees at Hopkins. Howard Naffziger (Fig. 2) traveled to Baltimore from California to serve as Cushing's last surgical resident from 1912 to 1913, but, due to his mother's ill health, he returned to California and eventually developed neurosurgery at the University of California, San Francisco. After practicing general surgery, Naffziger's interest in neurosurgery reemerged while at war, and his impact in 


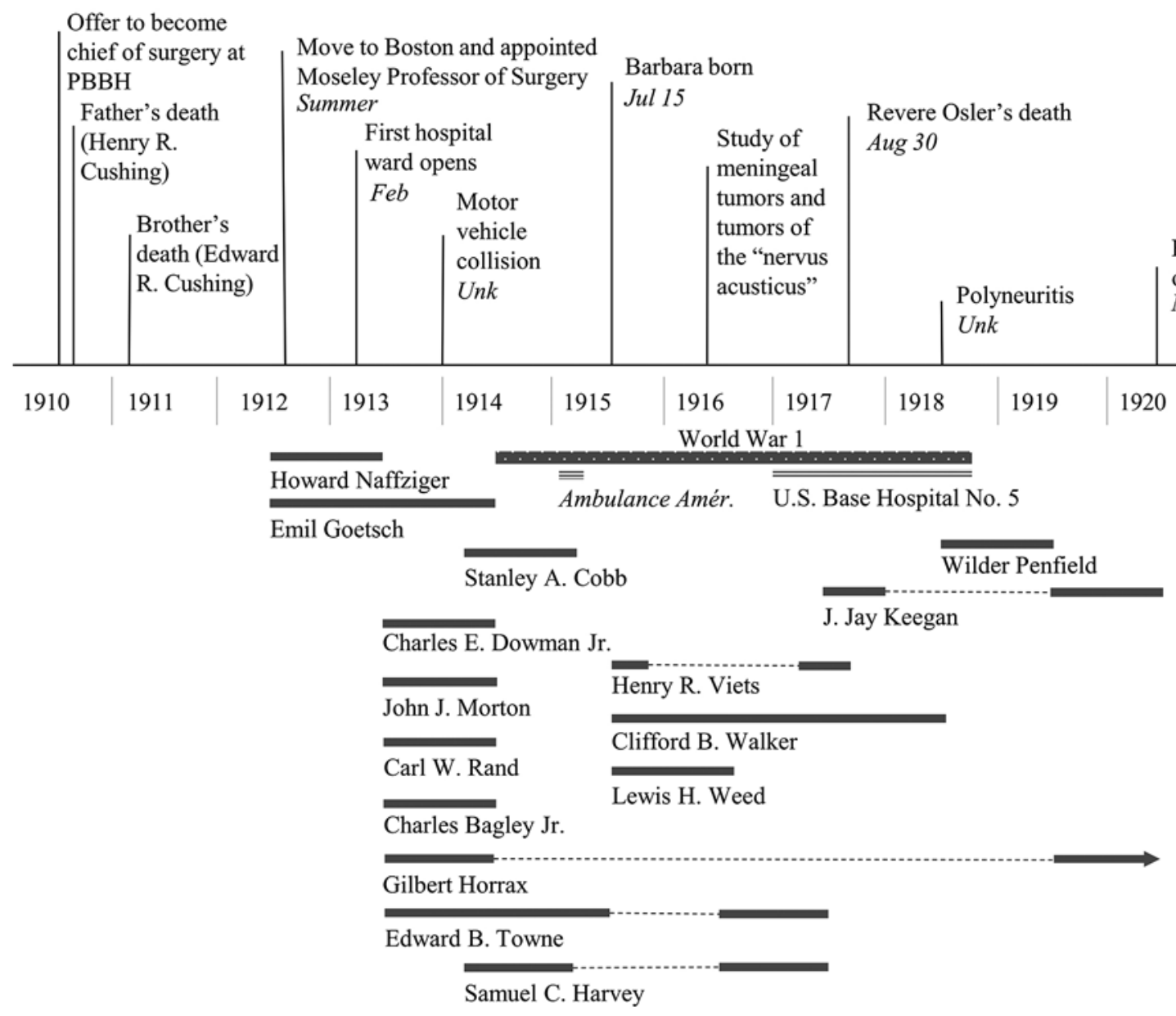

FIG. 1. Timeline from 1910 to 1920 showing significant events in the personal and professional life of Harvey Cushing (upper) and training periods of key people in the history of neurological surgery (lower). Solid bars represent an estimated period of near-continuous training. Dotted lines connect different continuous training periods for the same individual. Information obtained from the first through sixth annual reports (1914-1919) of the Peter Bent Brigham Hospital. https://nrs.harvard.edu/urn-3:HMS. COUNT:22846659. The time period for World War I is shown (center). The US involvement in the war began on April 6, 1917. Amér. = Américaine; $\mathrm{PBBH}=$ Peter Bent Brigham Hospital; unk = unknown.

California seems greatly influenced by an exchange of letters with Cushing from 1920 to $1940 .^{15}$ Naffziger admired Cushing and sought his advice. Cushing was proud of Naffziger's work on the shift of a calcified pineal gland as the roentgenographic sign of unilateral cerebral edema, ${ }^{32}$ and inspired Naffziger never to abandon the superior standards he had learned. ${ }^{26}$

In 1912, Harvey Cushing wrote to his wife, Kate, "the simple life slips away, alas,"1 and marked the beginning of a challenging time in their lives. He moved to Boston in September with little to do, and the hospital ward did not open until the following January. ${ }^{11}$ He was tasked with establishing a new laboratory, a new department, and a new specialty training program. Then, reportedly, Cushing was involved in a motor vehicle accident with an elderly pedestrian, resulting in her death. Although Cushing was not at fault, he no longer drove and relied on his Austrian gardener, "Gus," as a chauffeur.,11 In August 1914, while fishing in Canada, Cushing received word of the declaration of war. ${ }^{11}$ In 1915, Cushing led the Harvard unit for 3 months at the Ambulance Américaine in Paris. Cushing returned in May 1915 and celebrated the birth of his fifth child, Barbara, on July 15.11 All the while, he and William Keen were preoccupied with surgical preparations for war. ${ }^{11,14} \mathrm{He}$ finally returned to France in 1917 to control the US Base Hospital No. 5 (Fig. 3) and stayed until the end of the war. He encountered the tragedies of war, dealt with the death of Revere Osler, and suffered a debilitating polyneuritis. ${ }^{6,11}$

\section{Neurosurgical Training and the First World War}

Among Cushing's first resident trainees at the Brigham were Carl Rand, Edward Towne, Charles Bagley Jr., Charles Dowman Jr., John Morton, and Samuel Harvey (Table 1). Rand took the Hunterian canine surgery course in 1910, where Cushing was instrumental in Rand's maturation as a physician. Rand was complaining about the challenges of anesthesia, calling canines uncooperative, to 


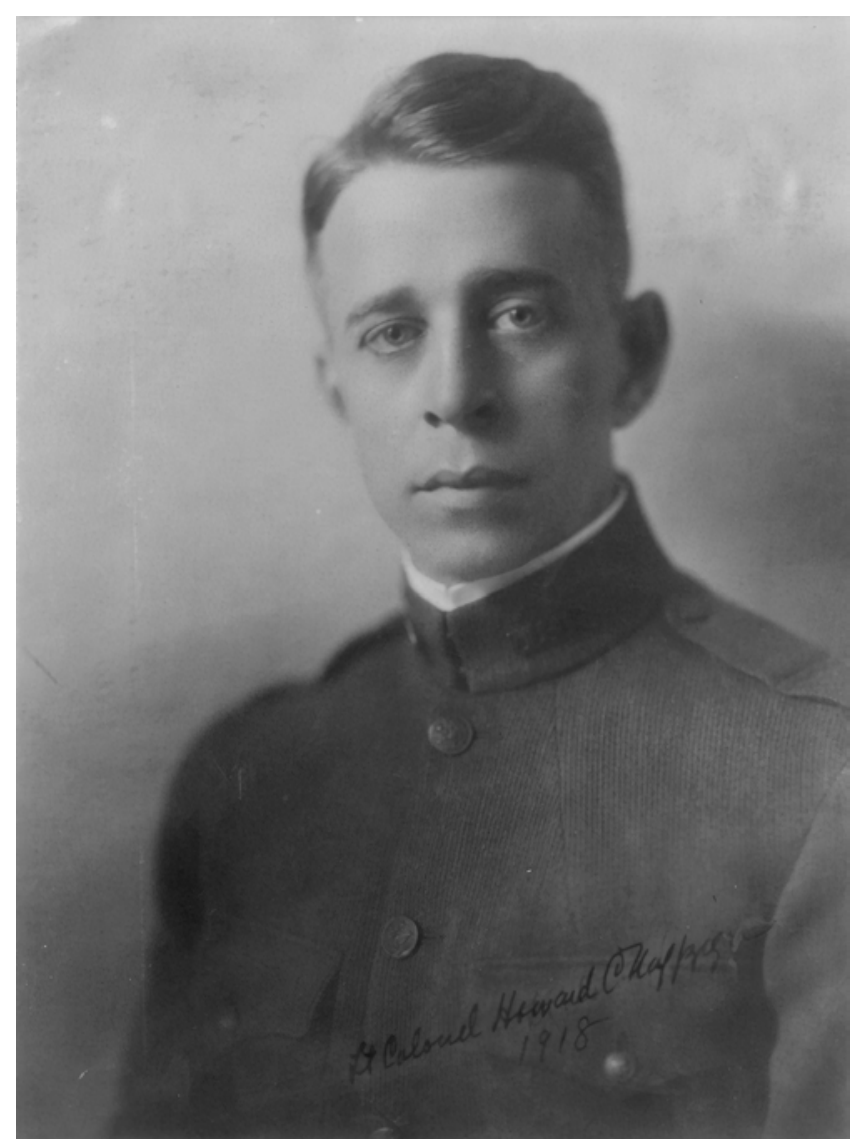

FIG. 2. Howard Christian Naffziger (1884-1961) in military uniform, World War I. Public domain. Modified from the digital resource published by the Regents of the University of California. Item featured on the website "A History of UCSF"; history.library.ucsf.edu. which Cushing replied, "Don't blame your golf balls."15 A few years later, as a surgical intern at Hopkins, Rand's composure in the management of a patient with suspected intracranial hypertension led Cushing to offer him a position at the Brigham. In 1914, Cushing allowed Rand to be the lead surgeon on the decompression of a cystic ependymoma, and Rand joined Cushing in the war. ${ }^{14}$ Afterward, Rand returned to California and practiced general surgery. He eventually limited his practice to neurosurgery and founded neurosurgery at the Los Angeles County General Hospital. ${ }^{15,25}$ Following Rand was Edward Towne (Fig. 4), who graduated from Harvard Medical School in 1913 and began his internship at the Brigham, where he assisted Cushing in 24 brain tumor operations..$^{15}$ Unlike Cushing's perfection of surgical technique, Towne's contributions during the war, largely influenced by British surgical philosophy of the time, were more practical and generalizable (see his series on finger exploration of gunshot wounds, where he notes that Cushing's catheter technique is more successful in the hands of an experienced surgeon ${ }^{29}$ ). In 1919, Towne returned to California, where he began neurosurgical practice at Stanford University Hospital. ${ }^{15}$ His notable scientific contributions include one of the first reports of radiation treatment of pituitary tumors ${ }^{28}$ radiographic identification of petrous bone erosion from acoustic nerve tumors, ${ }^{27}$ and the Towne projection for skull radiographs. ${ }^{3}$

Charles Bagley left home at 18 years of age and, without a high school diploma, funded his own medical school tuition at the University of Maryland, eventually graduating second in his class. ${ }^{12} \mathrm{He}$ became a wartime leader in the care of head-injured patients. Perhaps Bagley's greatest contribution was within the Surgeon General's Office as head of the Brain Surgery Section. He was charged with

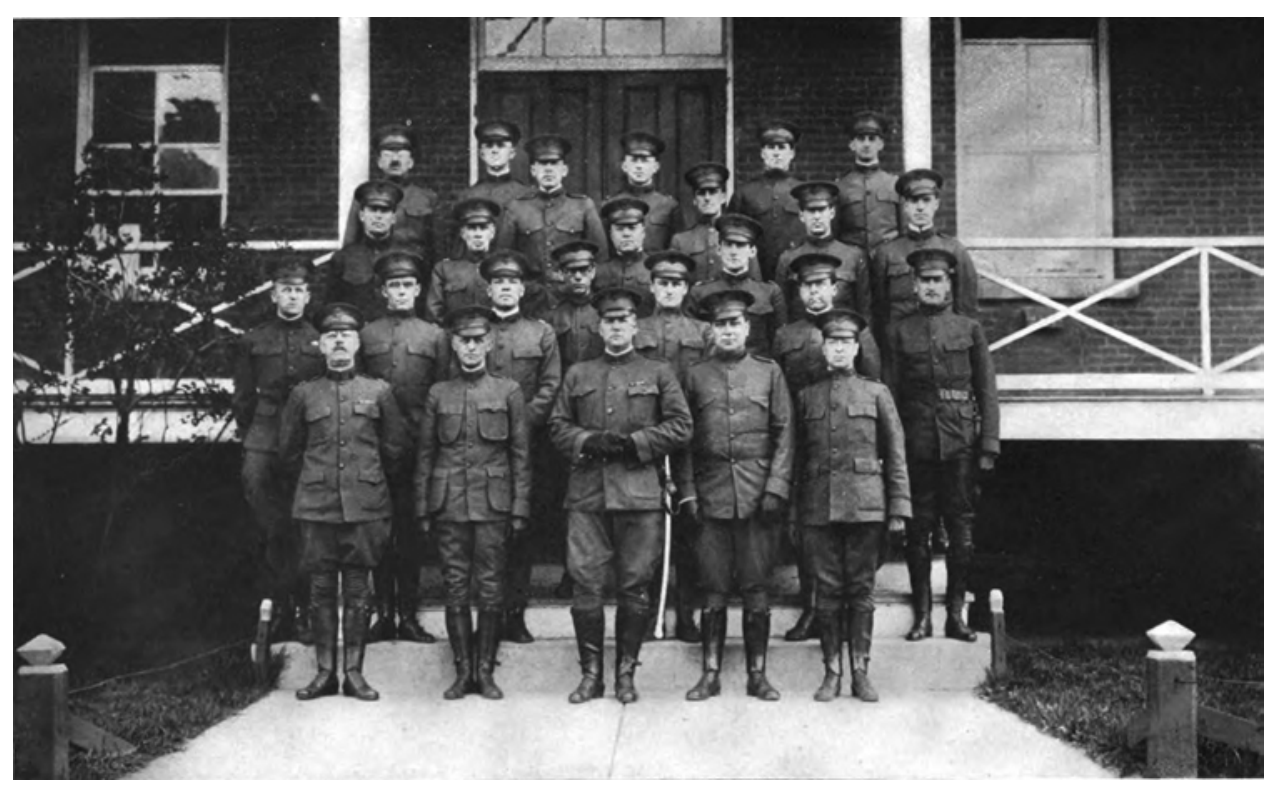

FIG. 3. The Officers of US Base Hospital No. 5 (Harvard Medical School Unit), photograph taken at Fort Totten, New York, May 10, 1917. Back row: Edward Towne (third from left) and John Morton (far right). Second row: Gilbert Horrax (far right). Front row: Harvey Cushing (second from left). From a Member of the Unit: The Story of U.S. Army Base Hospital No. 5. Cambridge: The University Press, 1919. Public domain. 
TABLE 1. Harvey Cushing's trainees from 1912 to 1919

\begin{tabular}{|c|c|c|c|}
\hline Name & Appointment & Dates & Eventual Position/Location \\
\hline Howard Naffziger & Assist resident & $1912-1913$ & Prof NS/UCSF \\
\hline Emil Goetsch & Resident surgeon & $1912-1915$ & Chief surgery/Long Island College Hospital \\
\hline Charles E. Dowman Jr.* & Staff & 1913 & Chief NS/Emory \\
\hline John J. Morton & Surgery house officer & 1913-1914 & Prof NS/University of Rochester \\
\hline Carl W. Rand & Assist resident surgeon & $1913-1914$ & Prof NS/USC (LA County Hospital) \\
\hline Charles Bagley Jr. & Assist resident surgeon & $1913-1914$ & Prof NS/University of Maryland \\
\hline Gilbert Horrax & $\begin{array}{l}\text { Surgery house officer } \\
\text { Assoc in NS }\end{array}$ & $\begin{array}{l}1913-1914 \\
1919-1932 \\
\end{array}$ & $\begin{array}{l}\text { Prof NS/Harvard PBBH } \\
\text { Prof NS/Lahey Clinic }\end{array}$ \\
\hline Edward B. Towne & $\begin{array}{l}\text { Surgery house officer } \\
\text { Assist resident surgeon } \\
\text { Assist resident surgeon }\end{array}$ & $\begin{array}{l}1913-1914 \\
1914-2015 \\
1916-1917\end{array}$ & Prof NS \& Surgery/Stanford \\
\hline Samuel C. Harvey & $\begin{array}{l}\text { Surgery house officer } \\
\text { Assist resident surgeon }\end{array}$ & $\begin{array}{l}1914-1915 \\
1916-1917\end{array}$ & Prof NS \& Surgery/Yale \\
\hline Stanley A. Cobb & Surgery house officer & $1914-1915$ & $\begin{array}{c}\text { Prof neuropathology/HMS } \\
\text { Assist neurology \& psychiatry/JHMS }\end{array}$ \\
\hline Lewis H. Weed & Laboratory fellow & 1915 & Dean/JHMS \\
\hline Clifford B. Walker & Assoc in surgery & 1915-1918 & Prof ophthalmology/HMS \\
\hline Henry R. Viets & $\begin{array}{l}\text { Voluntary assist } \\
\text { Surgery house officer }\end{array}$ & $\begin{array}{l}\text { July-September } 1915 \\
\text { March-August } 1917\end{array}$ & Prof neurology/HMS; curator, Boston Medical Library $†$ \\
\hline J. Jay Keegan & $\begin{array}{l}\text { Pathology house officer } \\
\text { Surgery house officer }\end{array}$ & $\begin{array}{l}\text { June-December } 1917 \\
\text { 1919-1920 }\end{array}$ & Prof NS/University of Nebraska \\
\hline Wilder Penfield & Surgery house officer & $1918-1919$ & Prof NS/MNI \\
\hline
\end{tabular}

Assist = assistant; assoc = associate; HMS = Harvard Medical School; JHMS = Johns Hopkins Medical School; LA = Los Angeles; MNI = Montreal Neurological Institute; NS = neurosurgery; PBBH = Peter Bent Brigham Hospital; prof = professor; UCSF = University of California, San Francisco; USC = University of Southern California.

Unless noted otherwise, the information was obtained from the first through sixth annual reports (1914-1919) of the Peter Bent Brigham Hospital. https://nrs.harvard. edu/urn-3:HMS.COUNT:22846659.

* Dowman's time at the Brigham is recorded in Society of Neurological Surgeons: The Society of Neurological Surgeons: 90th Anniversary 1920-2010. Winston-Salem, NC: Creative Communications, Wake Forest University School of Medicine, 2010.

$\dagger$ The Boston Medical Library later combined with the Harvard Medical Library to become the Countway Library.

delivering more than 300 brain surgeons to France for the war. He developed short subspecialty training courses; the first, led by Charles Frazier, was opened in Philadelphia, and one of its initial attendees was Charles Edward Dowman Jr., a general surgeon from Georgia. He worked under Cushing for 6 months at the Brigham in 1913. He joined the army at Camp Gordon in Blois, France, with Base Hospital No. 48 doing neurosurgery. Dowman and Cushing's other trainees revolutionized the care provided to head-injured patients during the war. Their reported $60 \%$ survival rate was astounding for the time. Dowman returned to Atlanta in 1919. He eventually became the chief neurosurgeon at Emory University, his alma mater. ${ }^{12}$ Bagley went on to be professor and head of the Section of Neurosurgery at the University of Maryland, where he started their resident training program.

John J. Morton followed Cushing to the Brigham after completing medical school at Hopkins. Morton also served with Cushing during the war, and Cushing assisted with his first case. After returning to camp, Cushing spent the evening "in a futile endeavor to resuscitate disconsolate Johnnie Morton's... patient," who had "respiratory failure from a spreading intracerebral hemorrhage." Morton served as the first chairman of surgery at the
University of Rochester, New York, where he performed the department's first neurosurgical procedures. In 1928, he hired Dr. William Perrine Van Wagenen as the first neurosurgical specialist and chief of the new Division of Neurosurgery. ${ }^{16}$

Samuel Harvey trained under Cushing from 1913 to 1917 and received the Arthur Tracy Cabot Fellowship before joining Cushing at Base Hospital No. 5. After the war, Harvey began an active practice of neurosurgery at Yale and eventually became the chairman of surgery in 1924. He established the Yale general surgery residency, followed by surgical subspecialty residencies, including neurosurgery. ${ }^{10,25}$ Harvey was interested in history, economics, and education and is credited with developing the "Yale System" of teaching. ${ }^{25}$

These 6 men, Rand, Towne, Bagley, Dowman, Morton, and Harvey, must have had tremendous trust in Cushing. They took on short-term training opportunities during Cushing's first 2 years as the head of a new department, with war on the horizon, and blazed the path of a new specialty. During the formative years of their professional lives, these fledgling neurosurgeons were molded by the mentorship of Harvey Cushing. They possessed the confidence and courage to be pioneers and carried on Cush- 


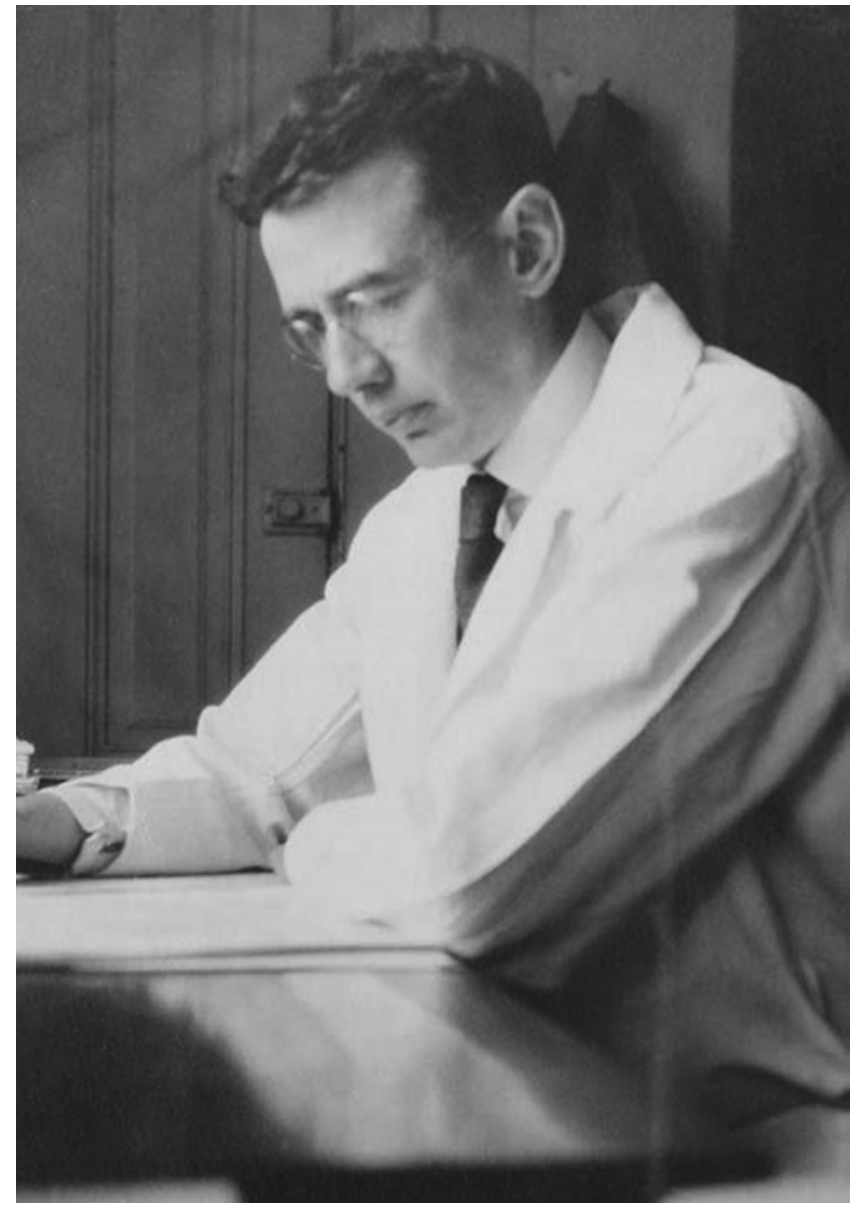

FIG. 4. Edward Bancroft Towne (1883-1957). Courtesy of the Stanford Medical History Center, Lane Medical Library, lane.stanford.edu/medhistory/index.html.

ing's philosophy of neurosurgical education, leading to the formalized practice of neurosurgery in 5 major universities across the US.

\section{The Diversity of Neurosurgical Mentorship}

It was not only neurosurgical assistants destined for the spawning of new programs that attracted Cushing's interest. His relationships with Clifford Walker, Lewis Weed, Emil Goetsch, Stanley A. Cobb, and J. Jay Keegan shed light on the fact that Cushing did not just care about advancing neurosurgery for the sake of neurosurgeons but also for the advancement of medical science and for the good of physicians in general.

Clifford Walker (Fig. 5), an ophthalmologist, worked with Cushing as an associate professor at Johns Hopkins and followed Cushing to Boston. Cushing and Walker began performing perimetry for the study of visual disease associated with brain tumors. ${ }^{2}$ Today, these findings represent the foundation on which we understand optic pathway disease and how the visual examination alone oftentimes leads to the diagnosis of pituitary tumors affecting the optic chiasm.

Lewis Weed (Fig. 6) first met Harvey Cushing as a

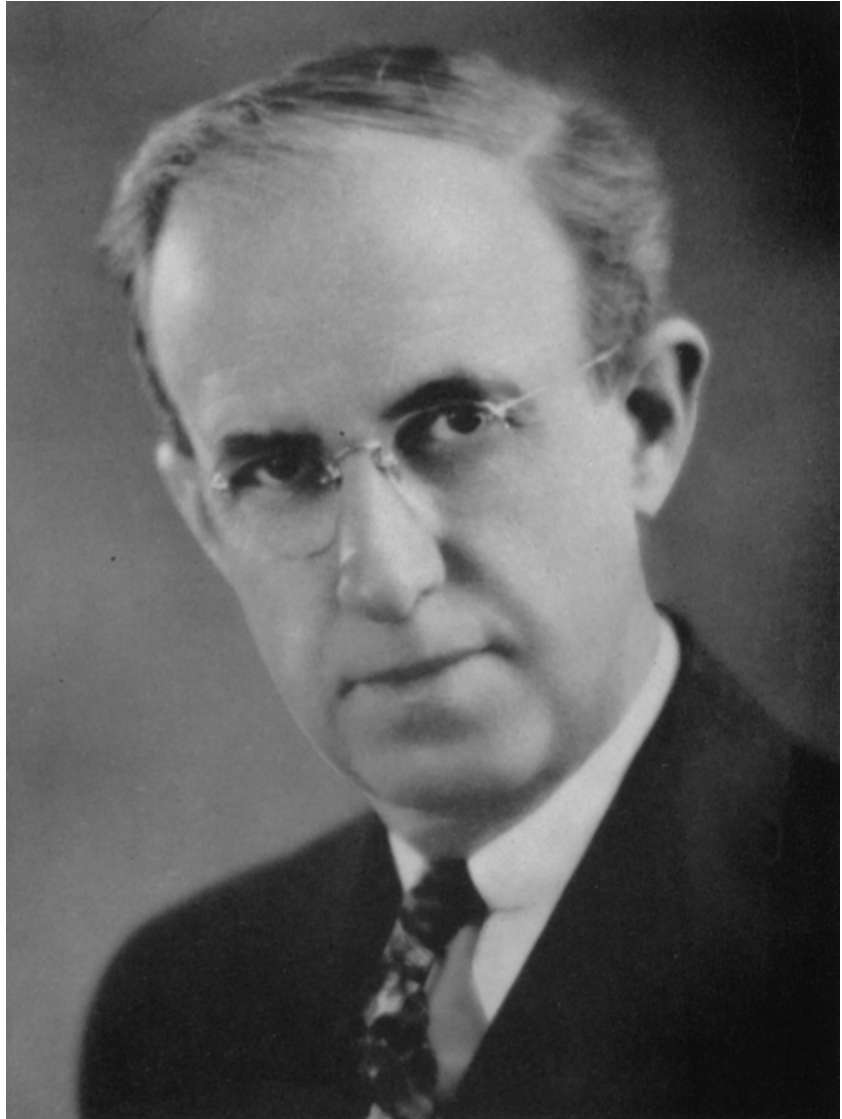

FIG. 5. Clifford B. Walker (1884-1943). From his obituary by Carl Fisher, Los Angeles, California. Photograph public domain. Reprinted from Fisher C: Clifford B. Walker, M.D. 1884-1943. Arch Ophthalmol 30(3):379-380, 1943.

medical student when Weed was working in the Hunterian Laboratory. ${ }^{4}$ Cushing cited and praised Weed's work in the laboratory during the Cameron Prize Lectures of 1925, which speaks to Cushing's admiration of this young scientist. As soon as Cushing arrived at Harvard, he appointed Weed to the Arthur Tracy Cabot Fellowship for assistants in charge of his laboratory. ${ }^{4}$ This same designation was given to Gilbert Horrax (1914) and Samuel Harvey (1915). Weed, the physiologist and laboratory assistant, made critical contributions in the understanding of intracranial pressure and the effect of intravenous hypertonic solutions on brain edema, but his greatest influence was as a research professor. According to John Fulton, author of Weed's obituary, Weed made it clear that his students were being educated for the assumption of a responsibility elsewhere - a principle Weed himself learned from Cushing. ${ }^{4}$ Weed eventually became dean of the Johns Hopkins Medical School in 1923.

Emil Goetsch was an MD, PhD, who worked with Weed in the Hunterian Laboratory and followed Cushing, as a surgical resident, to the Brigham. ${ }^{1,21}$ There, Goetsch studied pituitary function. ${ }^{9} \mathrm{He}$ demonstrated that giving pituitary extract to young rats increased their growth rate. His interest in endocrinology eventually prompted the organization of the Endocrine Society. ${ }^{17}$ 


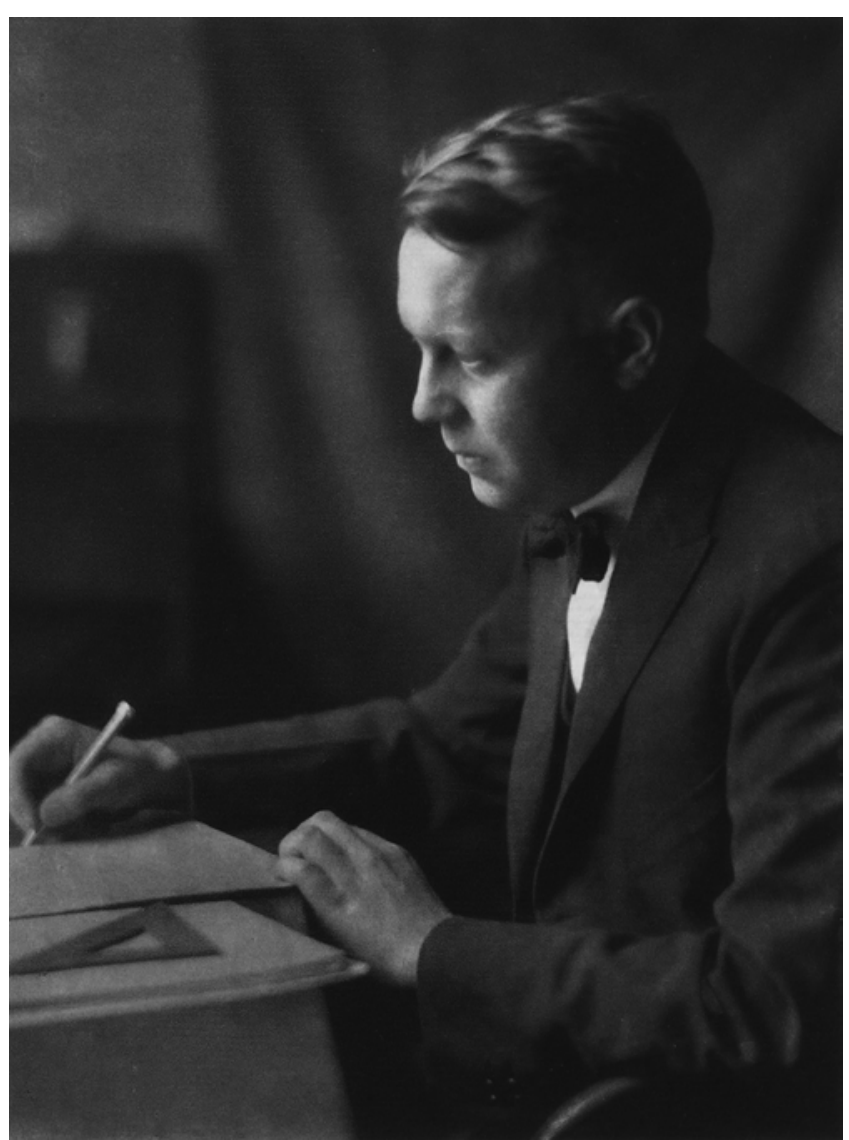

FIG. 6. Lewis Hill Weed. Photo by Doris Ulmann. From Ulmann D: A Book of Portraits of the Faculty of the Medical Department of the Johns Hopkins University Baltimore. Baltimore: The Johns Hopkins Press, 1922. Public domain.

Stanley A. Cobb, later the Bullard Professor of Neuropathology at Harvard Medical School, trained in surgery with Cushing from 1914 to 1915 before residency in neurology and psychiatry at Johns Hopkins. He was a first lieutenant in the US Medical Corps and is considered the founder of modern "biological psychiatry." ${ }^{24}$ His contribution to Cushing's birthday volume in the Archives of Surgery was a quantitative study of capillaries in the hippocampus. ${ }^{5}$

J. Jay Keegan was a neuroanatomist and began training as a pathology house officer in 1917. He served in the US Navy Medical Reserves at Chelsea Naval Hospital from 1918 to 1919 and studied pathology there. He was offered a position in clinical pathology and bacteriology at Harvard, but Keegan decided to return to the Brigham, where he trained with Cushing until 1920. Subsequently, he was appointed as professor of pathology and surgery at the University of Nebraska College of Medicine. By 1923, Irving S. Cutler, the dean at the time, assigned all neurosurgery at the University Hospital to Keegan. ${ }^{13}$

\section{Colleague, Protégé, Friend}

The last of Harvey Cushing's trainees to begin during wartime in America, and during the early formative years
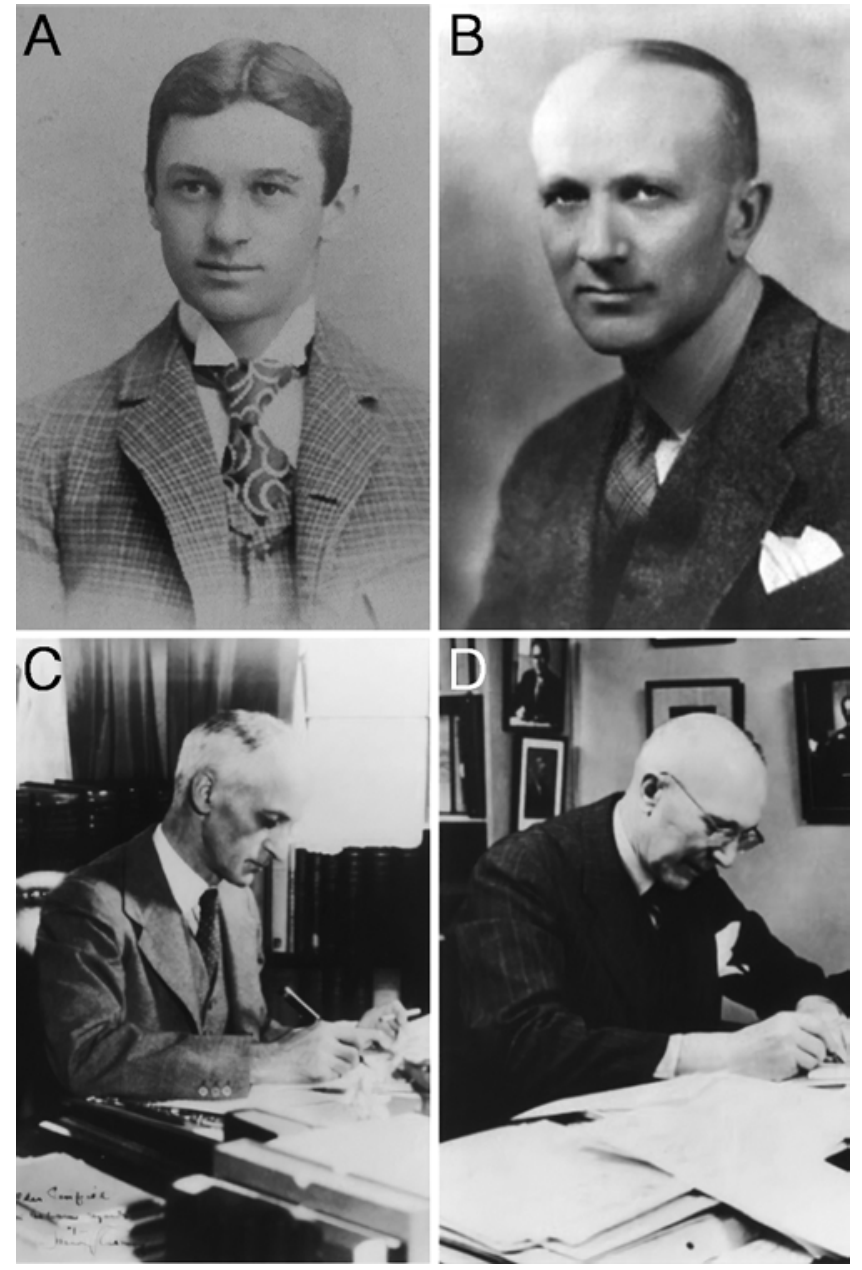

FIG. 7. A: Harvey Cushing as an undergraduate at Yale. Public domain. From Grauer NA: The Special Field: A History of Neurosurgery at Johns Hopkins. Baltimore: JHU Department of Neurosurgery, 2015. B: Wilder Penfield in 1934. From McGill University Archives. Public domain. C: Portrait of Cushing, fountain pen in one hand, unlit cigarette in the other (around 1924). D: In nearly the same pose as Cushing, Penfield writing at his desk in 1952. Panels C and D: (C) Montreal Neurological Institute. All rights reserved.

of Cushing's own career, were Wilder Penfield, Gilbert Horrax, and Henry Viets. Penfield (Fig. 7) led a parallel life to Cushing in the global advancement of the neurosciences and was always reverent when mentioning Cushing in letters. Horrax's 13 years as an assistant is double the training required today. It was being part of the Cushing team that Horrax cherished; Horrax was "made out of the kind of reinforcing steel that all teams built around a dominating tower must have."' Henry Viets, with Arnold Klebs, somehow elicited the boyish joys Cushing experienced when learning about history, medicine, and the world.

Wilder Penfield was a Rhodes Scholar from Princeton in 1915 and, like Cushing, was mentored by William Osler. ${ }^{31} \mathrm{He}$ volunteered at the French military hospital in the Ris-Orangis commune outside Paris and on the SS Sussex, where he was injured by a German U-boat torpedo. Penfield studied at Hopkins for medical school, graduat- 
ing in 1918, and trained as a surgical house officer at the Brigham but was eager to return to Oxford. His friendship with Cushing would be forged by parallel lives rooted in the training of physicians and their philosophical approaches to the emerging field of neuroscience. ${ }^{22}$ Notably, at the time Penfield was with Cushing, Cushing was just returning from war, where he cared for the mortally wounded Revere Osler, William Osler's only son. Penfield recovered from his own wounds under the care of the Oslers in Oxford. Penfield became fascinated with the study and surgery of the brain but differed from Cushing in certain philosophical aspects. ${ }^{22}$ Penfield emphatically believed that surgical neurology required the combination of neurosurgery, neuropathology, and clinical neurology. Accordingly, after leaving the Brigham, he returned to Oxford to work in Charles Sherrington's laboratory. He learned the "Spanish methods" of nerve staining, originally developed by Ramón y Cajal, from Pío del Río Hortega and then returned to New York for residency training at Columbia. Penfield founded the laboratory of neurocytology at the NewYork-Presbyterian Hospital. ${ }^{19}$ While in Europe, Penfield corresponded with Cushing regularly, including letters pertaining to the illness of their mutually respected mentor, Sir William Osler, around the time of Osler's death. ${ }^{22}$ It is evident that Cushing wanted Penfield to join him at the Brigham, but Penfield never seemed to elaborate on his rationale for declining to join Cushing. Perhaps Penfield wanted to carve his own path. He seemed keenly aware of their differences and leadership styles, and yet, as evident through personal letters, retained the utmost respect for Cushing as the leader of neurosurgical progress around the world..$^{19,20,22}$

Gilbert Horrax (Fig. 8) was appointed assistant surgical resident under Harvey Cushing in 1915 after Edward Towne resigned and departed for England. His formative introduction to Cushing was actually in France at the US Base Hospital No. 5 in 1917. Horrax made an impression on Cushing, and, on return to the Brigham, Horrax was appointed as Cushing's dedicated assistant, as well as a "safety valve and self-sacrificing fellow-laborer" for over a decade until Cushing's retirement in $1932 .{ }^{18}$ As the proverb goes, "iron sharpens iron, and one man sharpens another" (Proverbs 27:17). This was surely true with Cushing and Horrax. On Cushing's retirement, Frank H. Lahey invited Horrax to join the Lahey Clinic and add neurosurgical specialization to his exceptional enterprise. Donald Munro, an esteemed colleague, wrote, "training in [Horrax's] clinic has been the mecca for all aspiring neurosurgeons of whatever nation." 18 Horrax exemplified extraordinary intellectual honesty, innate unblemished modesty, and trustworthiness. Even those who questioned his opinions never disputed his facts.

Henry Viets was a neurologist and medical historian who met Cushing in 1915 during his final years of medical school..$^{30}$ Cushing invited Viets to lunch. The two met in Cushing's consulting room at the Brigham. Cushing was writing an operative note. Viets's account of their meeting speaks to Cushing's meticulous writing and illustrations of "considerable beauty." ${ }^{30} \mathrm{He}$ said that Cushing "spotted a stray [in Viets] and brought him into the fold." For Viets, this was a turning point in his life; it was an introduction

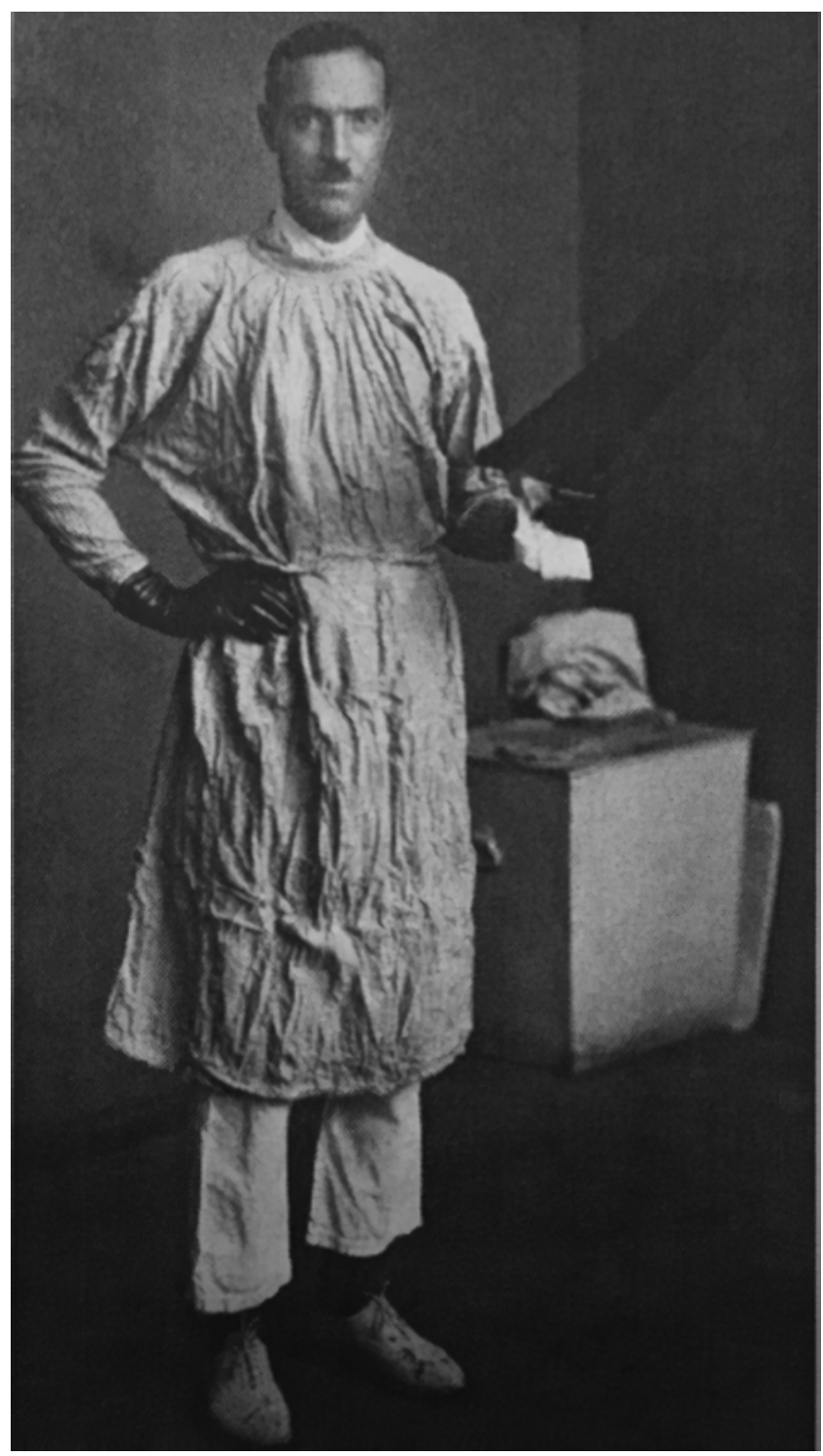

FIG. 8. Gilbert Horrax (1887-1957). Courtesy of Yale University, Harvey Cushing/John Hay Whitney Medical Library. Public domain.

to the culture of medicine and medical history. They visited the Boston Medical Library, where Cushing read from the Fabrica of Vesalius donated by Osler. Cushing's "quiet reverence" inspired Viets to appreciate the impact history and tradition can have on physicians. Viets then spent a year with Osler and continued regularly to correspond with Cushing. He and Cushing frequently visited Nyon, Switzerland, at Lake Geneva. In 1932, Viets and Arnold Klebs met Cushing in Geneva. Klebs was a leading authority on medical and scientific history at the time and was one of Cushing's closest friends. The friends embarked on a summer holiday through Europe where Klebs was the professor and chauffer and Cushing was "acting like a schoolboy... completely relaxed"; his role as the greatest neurosurgeon remained in the rearview mirror during his first visit to the Vatican Library. Perhaps Cushing the pupil had a far greater impact on Viets' life than Cushing 
the neurosurgeon. Cushing was decades older than Henry Viets, but their companionship in preserving the integrity and eloquence of medical history was transcendent.

\section{Concluding Remarks}

Herein, we see that the art of medicine is not conveyed in textbooks or computers, but in person. Mentorship is essential to the development of physicians and the advancement of science. Harvey Cushing, despite numerous barriers to effective mentorship, was able to use his intellectual energy and dedication to his trainees to launch an army of educators in neurosurgery into the world. Although, to our knowledge, Cushing never explicitly stated his philosophy of mentoring, it can be inferred from his actions and expectations of his trainees. In a letter to Percival Bailey in 1929, Cushing expressed his unyielding expectation for his trainees to surpass him. Cushing wrote,

[Norman Dott] is a fine lad and matured in just the way I hoped he would. I shall expect great things of him. It's a poor pupil that does not surpass his master, as Leonardo wisely said. ${ }^{23}$

We might add that it is a poor mentor who does not honor his/her own mentors by devoting precious time to principled nurturing of the future generation.

\section{References}

1. Bliss M: Harvey Cushing: A Life in Surgery. New York: Oxford University Press, 2005

2. Bose S, Patel V: Neuroimaging in neuroophthalmology. Neurosurg Focus 23(5):E9, 2007

3. Byrd SE, Harwood-Nash DC, Fitz CR, Barry JF, Rogovitz DM: Two projection computed tomography: the axial and Towne projections. Radiology 128:512-514, 1978

4. Carmel PW: Lewis Hill Weed: early neurosurgical contributor. Neurosurgery 17:114-117, 1985

5. Cobb S: The cerebral circulation. VIII. A quantitative study of the capillaries in the hippocampus. Arch Surg 18:12001209,1929

6. Cushing H: From a Surgeon's Journal: 1915-1918. Boston: Little, Brown, \& Co, 1936

7. Cushing H: The special field of neurological surgery. Cleveland Med J 4:1-25, 1905

8. Cushing H: The special field of neurological surgery after another interval. Arch Neurol Psychiatry 4:603-637, 1920

9. Cushing H, Goetsch E: Hibernation and the pituitary body. $\mathbf{J}$ Exp Med 22:25-47, 1915

10. Department of Neurosurgery: Origins of Neurosurgery at Yale. History of Neurosurgery. Yale School of Medicine (https://medicine.yale.edu/neurosurgery/about/history.aspx) [Accessed January 3, 2019]

11. Fulton JF: Harvey Cushing: A Biography. Springfield, IL: Charles C Thomas, 1946

12. Hanigan WC: Surgery of the head and 70-day brain surgeons. Neurosurgery 53:713-722, 2003

13. Keegan JJ: Early neurological surgery in Nebraska. Nebr State Med J 53:241-242, 1968

14. Keen WW: The Treatment of War Wounds. Philadelphia: WB Saunders Co, 1917

15. Keller TM: California's Cushing connection: Harvey Cushing trained California's first neurosurgeons. J Neurosurg 97:728-735, 2002
16. Kimmell KT, Petraglia AL, Bakos R, Rodenhouse T, Maurer PK, Pilcher WH: The history of neurosurgery at the University of Rochester. J Neurosurg 121:989-994, 2014

17. McCann SM (ed): Endocrinology: People and Ideas. New York: Springer, 1988

18. Munro D: Obituary. Gilbert Horrax 1887-1957. J Neurosurg 15:234-236, 1958

19. Penfield W: No Man Alone: A Neurosurgeon's Life. Boston: Little Brown, 1977

20. Penfield W: The passing of Harvey Cushing. Yale J Biol Med 12:323-326, 1940

21. Peter Bent Brigham Hospital: First Annual Report of the Peter Bent Brigham Hospital. Boston: Cambridge University Press, 1915

22. Preul MC, Feindel W: "The art is long and the life short": the letters of Wilder Penfield and Harvey Cushing. J Neurosurg 95:148-161, 2001

23. Prieto R, Pascual JM: Norman M. Dott, master of hypothalamic craniopharyngioma surgery: the decisive mentoring of Harvey Cushing and Percival Bailey at Peter Bent Brigham Hospital. J Neurosurg 127:927-940, 2017

24. Shorter E: A History of Psychiatry: From the Era of the Asylum to the Age of Prozac. New York: Wiley, 1997

25. Society of Neurological Surgeons: The Society of Neurological Surgeons: 90th Anniversary 1920-2010. WinstonSalem, NC: Creative Communications, Wake Forest University School of Medicine, 2010

26. Stern WE: Obituary. Howard Christian Naffziger 1884-1961. J Neurosurg 18:711-713, 1961

27. Towne EB: Erosion of the petrous bone by acoustic nerve tumor: demonstration by roentgen ray. Arch Otolaryngol 4:515-519, 1926

28. Towne EB: Roentgen-ray treatment of pituitary tumors. Arch Neurol Psychiatry 15:92-102, 1926

29. Towne EB, Goethals TR: Finger exploration of gunshot wounds of the brain. Ann Surg 71:531-559, 1920

30. Viets HR: Harvey Cushing: an anecdotal biography. Proc Mass Hist Soc 81:194-207, 1969

31. Wilder Penfield Digital Collection: Biography. McGill Digital Library (http://digital.library.mcgill.ca/penfieldfonds/ biography.php) [Accessed December 31, 2019]

32. Wilkins RH: Neurosurgical Classic-XXIX. J Neurosurg 22:196-200, 1965

\section{Disclosures}

The authors report no conflict of interest concerning the materials or methods used in this study or the findings specified in this paper.

\section{Author Contributions}

Conception and design: both authors. Acquisition of data: both authors. Analysis and interpretation of data: both authors. Drafting the article: both authors. Critically revising the article: both authors. Reviewed submitted version of manuscript: both authors. Approved the final version of the manuscript on behalf of both authors: Catalino.

\section{Correspondence}

Michael P. Catalino: Brigham and Women's Hospital, Boston, MA.mcatalino@bwh.harvard.edu. 